\title{
Archaeological Investigations at Mission Concepcion, Fall of 1986
}

Anne A. Fox

Follow this and additional works at: https://scholarworks.sfasu.edu/ita

Part of the American Material Culture Commons, Archaeological Anthropology Commons, Environmental Studies Commons, Other American Studies Commons, Other Arts and Humanities Commons, Other History of Art, Architecture, and Archaeology Commons, and the United States History Commons

Tell us how this article helped you.

This Article is brought to you for free and open access by the Center for Regional Heritage Research at SFA ScholarWorks. It has been accepted for inclusion in Index of Texas Archaeology: Open Access Gray Literature from the Lone Star State by an authorized editor of SFA ScholarWorks. For more information, please contact cdsscholarworks@sfasu.edu. 


\section{Archaeological Investigations at Mission Concepcion, Fall of 1986}

Creative Commons License

(c) (i) (8)

This work is licensed under a Creative Commons Attribution-NonCommercial 4.0 International License 


\title{
ARCHAEOLOGICAL INVESTIGATIONS AT MISSION CONCEPCION, FALL OF 1986
}

\author{
Anne A. Fox
}

Center for Archaeological Research The University of Texas at San Antonio Archaeological Survey Report, No. 172 





\section{ARCHAEOLOGICAL INVESTIGATIONS AT \\ MISSION CONCEPCION,}

FALL OF 1986

Anne A. Fox

Center for Archaeological Research The University of Texas at San Antonio ${ }^{\circledR}$ Archaeological Survey Report, No. 172

1988 
The following information is provided in accordance with the General Rules of Practice and Procedure, Chapter 41.11 (Investigative Reports), Texas Antiquities Committee:

1. Type of investigation: archaeological testing at Mission Nuestra Señora de la Purísima Concepción;

2. Project name: Mission Concepción Drainage;

3. County: Bexar County, Texas;

4. Principal Investigator: Thomas R. Hester; Co-Principal Investigators: Jack D. Eaton and Anne A. Fox;

5. Name and location of sponsoring agency: San Antonio Missions National Historical Park, San Antonio, Texas;

6. Texas Antiquities Committee Permit No. 586;

7. Published by the Center for Archaeological Research, The University of Texas at San Antonio, San Antonio, Texas 78285-0658, 1988.

A list of publications offered by the Center for Archaeological Research can be obtained by sending $\$ 1.00$ to the Center for Archaeological Research, The University of Texas at San Antonio, San Antonio, Texas 78285-0658. 


\begin{abstract}
In October 1986, the Center for Archaeological Research, The University of Texas at San Antonio, conducted limited test excavations at Mission Nuestra Señora de la Purísima Concepción (41 BX 12) for the San Antonio Missions National Historical Park. The purpose of the excavations was to determine whether buried wall footings and occupation surfaces were preserved in an area where a drain pipe was proposed to be installed to carry rainwater away from the convento. Eleven test units were excavated at points where the foundations of the first two-story convento were expected to cross the area. Remnants of the footings of the north and south walls of the convento were isolated, recorded, and reburied. No traces of occupation surfaces were found. Three electrical conduit lines were found to cross the area in question, two of which were unknowingly dug into the top of the north convento wall. Based on the findings of the testing, it is recommended that the trench for the drain be excavated by hand through the convento area.
\end{abstract}




\section{TABLE OF CONTENTS}

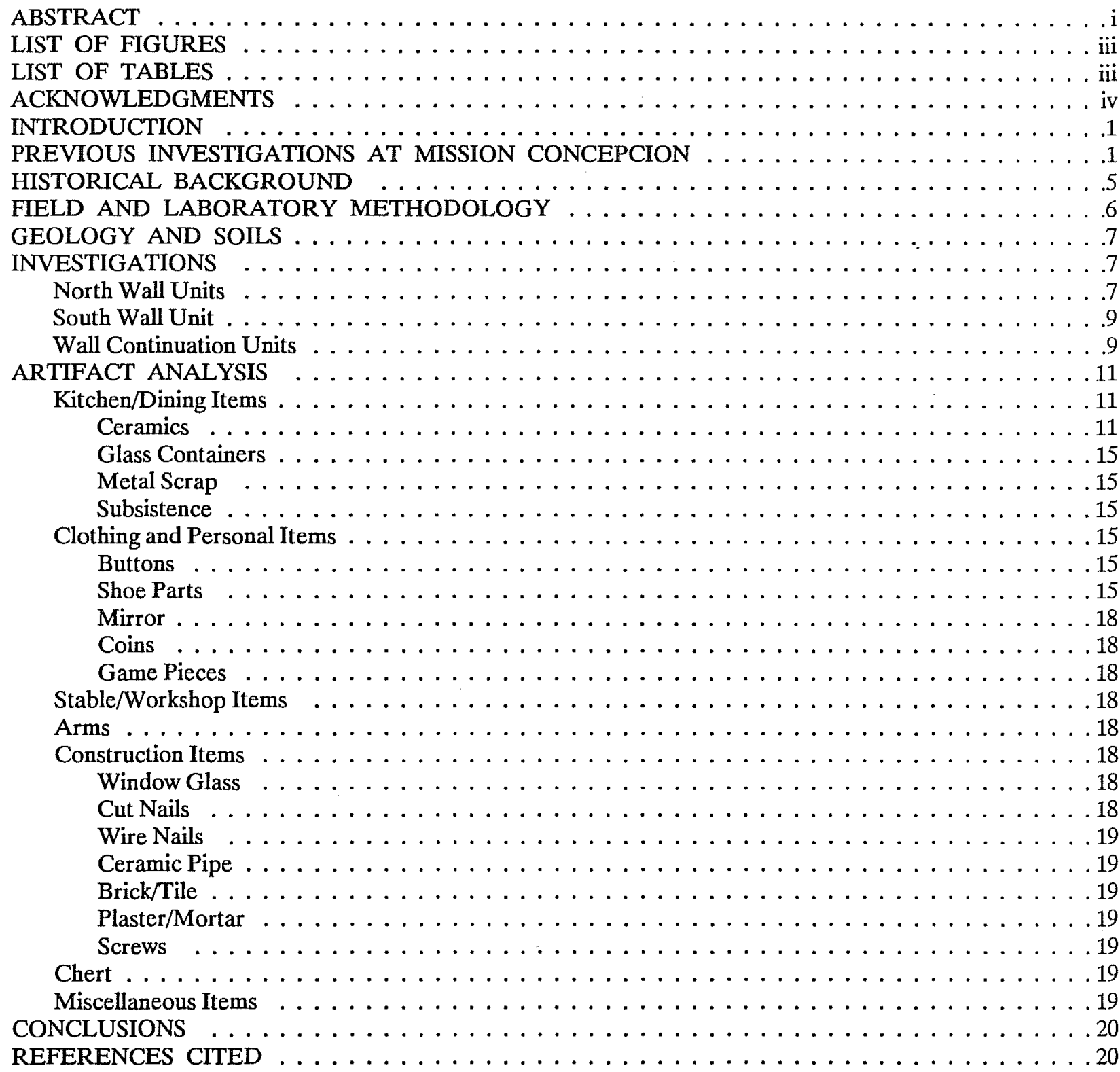




\section{LIST OF FIGURES}

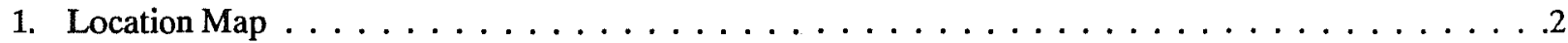

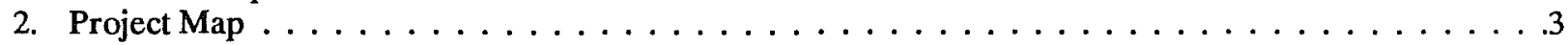

3. First Floor Plan of Church and Adjoining Structures $\ldots \ldots \ldots \ldots \ldots \ldots \ldots \ldots \ldots \ldots \ldots \ldots$

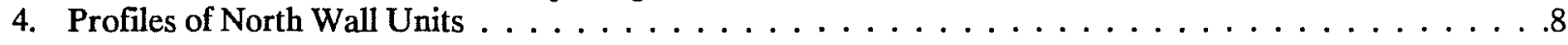

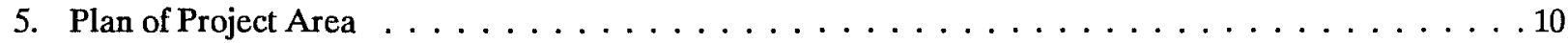

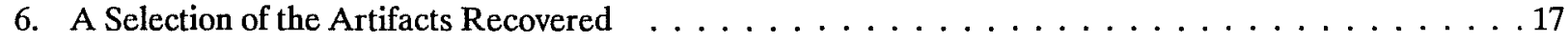

\section{LIST OF TABLES}

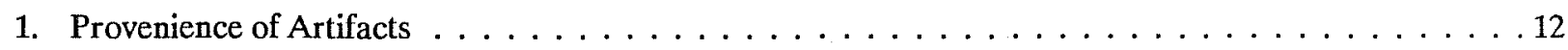




\section{ACKNOWLEDGMENTS}

In all, over 625 person hours were expended during the field work for this project. At least half of this total was volunteer time. We are grateful to the following volunteers: Kerri Bargas, Nancy Beaman, Pamela Butler, Waynne and Darla Cox, Cathy Dodt-Ellis, Kay Eades, Jim and Kerry Ellis, Santiago Escobedo, Joe Garant, Jeff Huebner, Stephanie Key, Rod Krehbiel, Rochelle Leneave, Michael Marchbanks, Don McEwan, Bruce Mergele, Frances Meskill, Shirley Mock, Marty Morrison, Duke Smith, and Jim and Joyce Warren.

Crew members were David Hunter, Bruce Ellis, Kelly Scott, and Paul Maslyk. Bruce Ellis and Cathy Dodt-Ellis ran the mapping crew and drafted the illustrations for this report. Ken Brown of the Center staff photographed the artifacts. Editor for the report was Sharon Quirk.

We are grateful for the help of John Leal, county archivist, and local historian Richard Garay for providing maps and documents to help with the historical research on the project.

Park superintendent José Cisneros and numerous park rangers were most helpful and interested in the project. We appreciate their aid in expediting the work.

Last, but by no means least, our thanks to Los Compadres de San Antonio Missions National Historical Park for financing and enthusiastically supporting the project and the publication of this report. 


\section{INTRODUCTION}

In October 1986, an archaeological crew from the Center for Archaeological Research, The University of Texas at San Antonio, conducted test excavations at Mission Nuestra Señora de la Purísima Concepción (41 BX 12) ca. three kilometers south of downtown San Antonio (Fig. 1). The work was done under contract with the National Park Service. Mission Concepción is a part of the San Antonio Missions National Historical Park. It is also a State Archeological Landmark, is listed on the National Register of Historic Places, and has been recorded by the Historic American Buildings Survey. The investigation was done in compliance with Section 106 of the National Historic Preservation Act of 1966 (as amended) and Executive Order 11593. Texas Antiquities Committee Permit No. 586 was issued for the project.

The work was accomplished in 10 working days by a crew of anthropology students under the direction of the author. David Turner served as field director, and Bruce Ellis was in charge of the mapping crew. Principal investigator for the project was Dr. Thomas R. Hester, director of the Center for Archaeological Research, with Jack Eaton, associate director, and Anne Fox as coprincipal investigators. Twenty-four volunteers aided in the excavations, contributing over 300 person hours to the project.

There has been a periodic problem of flooding in the low area of the mission between the sacristy and the convento (Fig. 2), with rainwater occasionally backing up and entering the convento doors. The purpose of the test excavations was to determine the best route (the one disturbing the least amount of archaeological resources) for a drain pipe to be installed in order to eliminate the problem. The challenge was to plan the testing so as to be as economical of time and manpower as possible and to do the least amount of disturbance to the archaeological resources present, in order to preserve the area.

\section{PREVIOUS INVESTIGATIONS AT MISSION CONCEPCION}

The Works Progress Administration (WPA) in the 1930s conducted excavations around the mission structures. Local architect Harvey P. Smith directed the work and mapped numerous buried foundations discovered by the WPA workers south of the convento (Fig. 3).

Several archaeological investigations have been carried out at the mission during the past 15 years. In the fall of 1971 and the spring of 1972, investigations under the direction of Dan Scurlock of the Texas Historical Commission tested the moisture and structural condition of the foundations of the mission church, tested an area south of the convento, and located traces of the west wall of the mission, long buried and forgotten in an open field across the present Mission Road from the main body of the mission (Scurlock and Fox 1977). Because he did not have access to Smith's drawings, Scurlock had no way of knowing that the section of stone foundation described as Feature 16 in Test Pit 71 (ibid::22) was actually a portion of the foundation of the first, two-story stone convento.

During the fall of 1981 and spring of 1982, the Center for Archaeological Research conducted selective test excavations to locate the original outline of the entire mission, to find the granary, and to assess the state of preservation of the Indian quarters along the walls of the pueblo. The report of these investigations is currently being prepared for publication by the Center for Archaeological Research (Ivey and Fox n.d.).

Test excavations at the south end of the granary revealed thick (45 inches) travertine block walls, earlier stone and adobe walls, and what appeared to be a series of packed earth and adobe floors. Ivey suggested that this rather confused picture is the result of demolition of an adobe structure, then building a stone structure over the resulting debris, and finally the construction of an early 19th-century house over all. This could also explain the noticeable rise in elevation in the vicinity of the south end of the granary (Fig. 2). Ivey believed that the second building phase (the first stone foundation) represents the walls of the first convento in this area (ibid.).

In preparation for writing a Historic Structures Report for the National Park Service, James Ivey (1982) conducted brief additional tests in the area of the first adobe church of Mission Concepción in the summer of 1982. In the process he found evidence for a sequence of building and demolition in the area, with related fragments of floors 


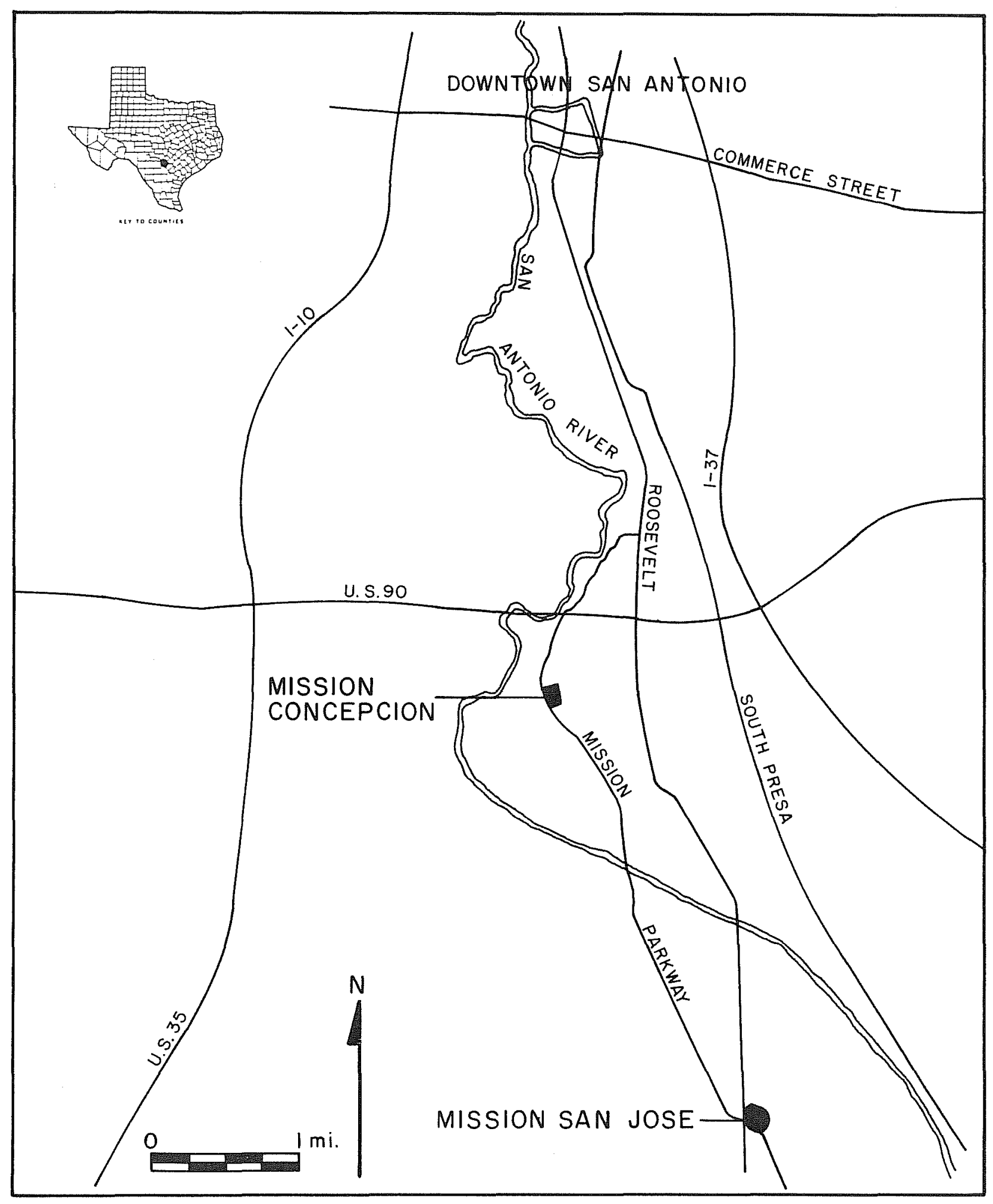

Figure 1. Location Map. 


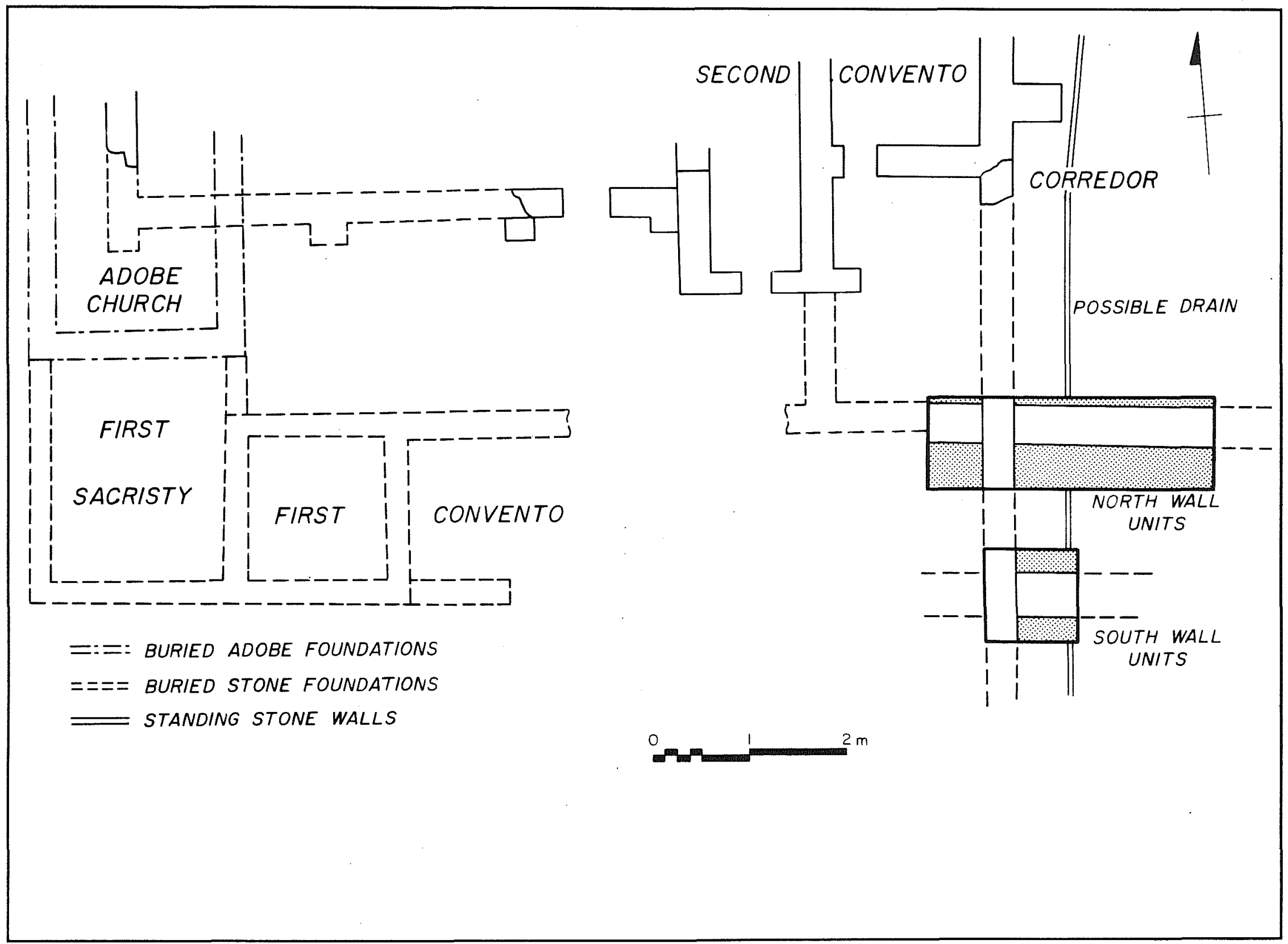


SCHEDULE gr ROOMS (1.) MAVE - BRICK FLOOR. Plaster WALLS AND CELLING.
(2) CWANCEL- BXB YELLOW AND OVER, PLASTERED. (3) SANCTUARY-YELLOW AND BLACK
THE PLOOR. PLASTER WALLS (ATRANSEPTS - FINISHED SIMILAR TO(3) (5) SACRISTY-BRICK PLOOR. PLASTER (6) BAPTISTRY AND CEILING. (7) TOWER ROOM- SIMILAR TO (6) (8)KITCHEN-DIRT FLOOR. PLASTER (a) STORE ROOM-DIRT PLOOOR.WALLS (1) SINTE ROOM AND CEILING PLASTERED. (1.) LIBRARY - SIMILAR TO OO. (1) WaLs AND CEILING. (i) CELLS- DIRT FLOOR. STONE WALLS
AND CEILING. NOTE: ROOMS 5. TO H. WERE AT ONE TIME DECORATED WITH WALL AND DISTINGUISHABLE NOW.

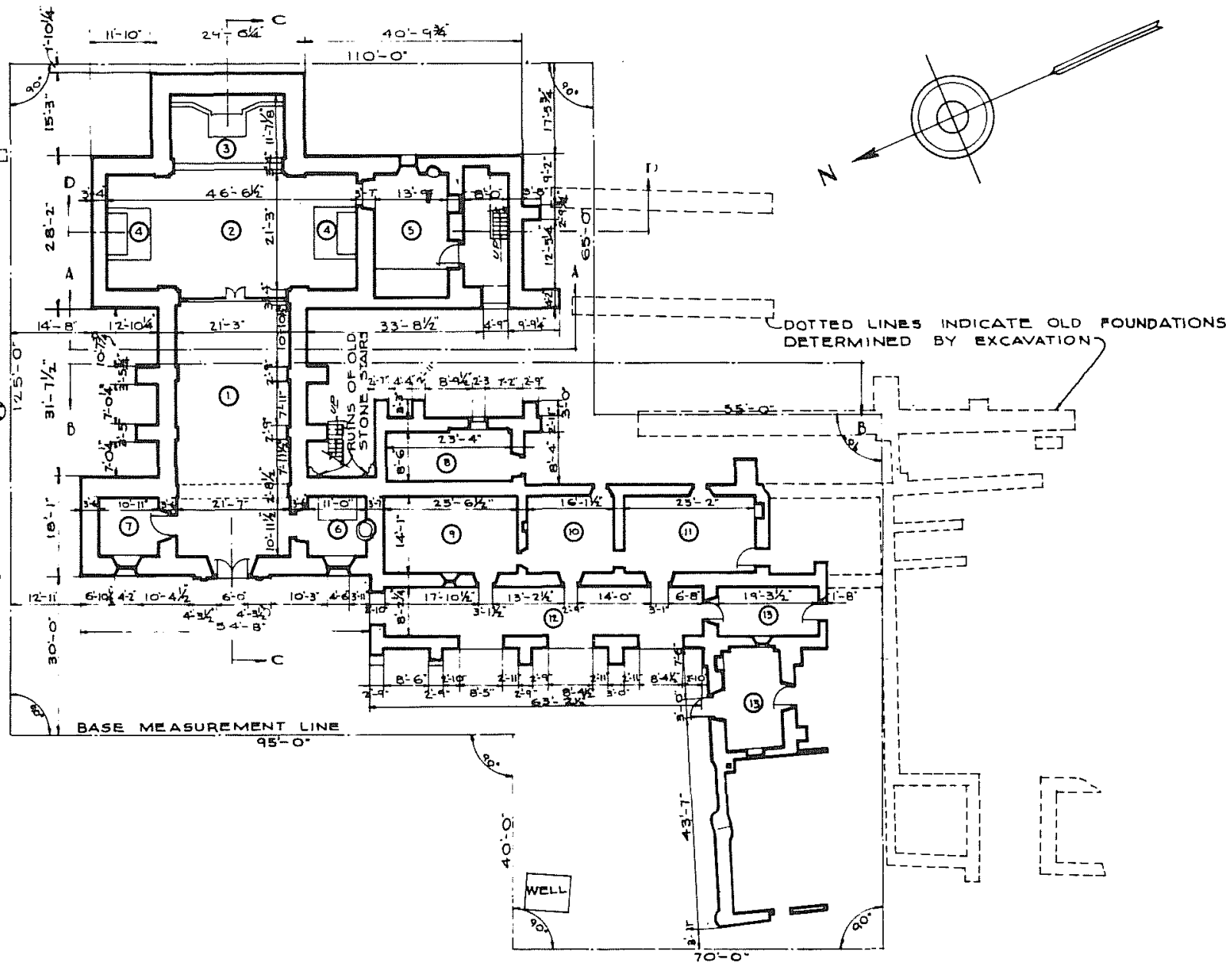

\section{FIRST FLOOR PLAN \\ SCALE: $1 / \sigma^{\circ}=1-0^{\circ}$}

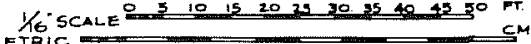
WORKS PROGRESS ADMINISTRATION
OFFICIAL PROJECT $269-6907$ MISSION PURISIMA NAME OF STRUCTURE 
and other occupation surfaces (ibid::18-21). A copy of the manuscript report on these investigations is on file at the Center. The resulting detailed Historic Structures Report (Ivey and Thurber 1984) has not as yet been published.

The results of all of these previous investigations have been useful in planning and carrying out the present testing, and reference will be made to them throughout the report.

\section{HISTORICAL BACKGROUND}

The following could in no way be considered a complete or exhaustive history of Mission Concepción, but is rather a general summary with particular emphasis on events that directly affected the area where this project's excavations were done. For a more comprehensive history, we refer the reader to Father Marion Habig's (1968) book, The Alamo Chain of Missions, A History of San Antonio's Five Old Missions.

In 1731, Mission Nuestra Señora de la Purísima Concepción was established on the San Antonio River near the Villa de Bexar. Previously named Nuestra Señora de los Dolores de los Tejas, the mission was given a new name and a site downstream from the villa when it was moved from its east Texas location in what is now Nacogdoches County. Some 300 Coahuiltecan Indians of the Pajalat and Pacao groups were persuaded to resettle at the new location (Castañeda 1936:241). Temporary buildings were built of adobe and jacal, and the work of the mission went forward.

By 1756 , a stone wall had been built around the compound, and a stone granary and a two-story stone friary, or convento, had been constructed and were in use (Habig 1968:129). A temporary, flat-roofed adobe church built ca. 1733 had been demolished (Ivey and Thurber 1984:3-42), and there was a newly completed stone church (ibid::346).

After this time, the population of the mission gradually declined. By 1762 , a new one-story convento had been partially completed. It was begun about 1756 as a series of vaulted rooms with a porch or corredor on either side, but for some reason in 1759 the vaulted construction was found to be unsuitable (Dolores y Biana 1759:microfilm roll 9 , frame 1493), and the order was given to build the rest in flat-roofed construction.

There were only 38 Indians still living at Concepción when the mission was partially secularized in 1794 . At that time the mission lands and possessions were divided among the Indian residents, with the exception of the church which continued in operation under the supervision of a missionary stationed at Mission San José, a short distance downstream (Habig 1968:141-142). The population at the mission continued to decline, although supplemented by Spanish citizens from the Villa de Bexar. Juan Antonio Padilla, in 1820 (Hatcher 1919:59), remarked that for three years citizens of the villa had been planting the fields of Mission Concepción, but without irrigation since they could not afford to rebuild the dam and clean the ditches. Padilla also described the general state of decay of the buildings. Apparently only the church and convento were still standing, the rest being merely "heaps of rubbish."

By about 1819, services ceased to be held in the church, the parishoners going instead to the church at Mission San José. In 1824, the mission was officially secularized, and the church was turned over to the pastor of San Fernando Church in San Antonio (Habig 1968:146). Even before official secularization, the Mexican government was selling the surrounding lands to local citizens. In 1823, the granary of the mission was sold to Manuel Yturri y Castillo. Yturri and his family lived in the building until he sold it to Asa Mitchell in 1838, after which time it apparently was never occupied again (Ivey and Thurber 1984:3-61).

A serious fire at San Fernando in 1828 apparently resulted in a general clean-up campaign by the residents of Mission Concepción. According to a list of persons who contributed to the repair of the church ( $B C A$ 1828:microfilm roll 118, frame 732), various Mission Concepción citizens contributed a total of 80 cartloads of stone. 
The gradual physical decline of the mission continued throughout the first half of the 19th century until the Brothers of Mary obtained title to the land in 1859. The mission was then used as a training school for the Society and a farm. The church was restored and rededicated in 1887 (Habig 1968:149).

The outlines of the mission compound had been nearly obliterated as the turn of the century approached (Corner 1890:16). The final blow to its integrity was the rerouting of Mission Road to its present location through the grounds about 1890 (BCDR Vol. 54:85).

Title to the mission buildings and the land on which they stood were transferred to the Bishop of San Antonio in 1911. The church was restored in 1913 and put into active use. St. John's Seminary was built in 1920 (Furey 1974:28) to the northeast of the church, just outside the original northeast corner of the mission compound. By this time the boundaries of the compound had no doubt been completely forgotten.

The arrival of the Redemptorist Order in 1922 to take charge of the mission signalled a time of important restoration and stabilization for the remaining buildings and the grounds. At this time, a buttress was added to the east wall of the convento, and a considerable amount of landscaping was done, including the introduction of palm trees and other exotic and tropical plants.

On November 10, 1978, Public Law 95-629 was passed by the 95th Congress, providing for the establishment of the San Antonio Missions National Historical Park (Cisneros 1980). From that time to the present, all of the San Antonio missions, with the exception of Mission San Antonio de Valero (The Alamo), have been under the administration of the National Park Service.

\section{FIELD AND LABORATORY METHODOLOGY}

When faced with the problem of plotting a course for the proposed drain pipe that would cause the least disturbance to archaeological remains, we first studied Harvey Smith's drawings of the buried foundations he found in the area. It appeared that the location most likely not to produce many complications would be the corredor that ran along the east side of the present convento. The drawings suggested that this corredor may have continued south of the currently standing buildings to a point beyond the park fence (Fig. 3). He shows the walls ending at that point, but there is no indication whether the wall stopped there or whether Smith's investigations went no farther south. If a major disturbance had eliminated the walls beyond this point, there would be no obstacle to carrying the drain pipe trench to the south across this area.

In order to determine whether there were preserved floors, wall foundations, or other occupational features present in the corredor, test units were laid out so as to examine walls indicated by Smith as crossing the corredor, as well as to sample the area for occupation surfaces or floors. Units were also located south of the park fence to determine the state of preservation of any ruins left in this area. Numerical designation for these units was begun at 100 so as to avoid confusion with designations from previous seasons' excavations.

One-meter-square units were excavated in 10-cm levels to sterile soil. All dirt removed was screened through 1/4inch mesh. Artifacts were placed in bags marked with their provenience and removed daily to the laboratory for processing. Elevations within the units were maintained with the aid of string and line level from a datum at the southwest corner of each square. Datum elevations were determined using transit and stadia rod. A detailed topographical map was made of the entire area south of the mission church, with a contour interval of $10 \mathrm{~cm}$ (Fig. 3).

All work was recorded on standard archaeological field forms, and daily logs were kept by the project director and the field director. Soil colors were recorded in reference to Munsell Soil Color Charts (1975). Black and white photographs and color slides were taken to document all phases of the work. These records, along with the artifacts recovered, are currently being curated for the National Park Service at the Center for Archaeological Research. 
In the laboratory, the artifacts were cleaned and marked according to their exact provenience, then laid out for analysis. Samples of soil, caliche, travertine, and plaster collected in the field were examined to positively establish their identification in order to help understand the structure of the site.

\section{GEOLOGY AND SOILS}

The mission is located on land slightly higher in elevation than the surrounding terrain, and would have commanded a view for some distance up and down the San Antonio River valley at the time it was constructed. From the mission the land slopes very gradually downward to the river channel to the west.

The site is situated within a general area of Venus-Frio-Trinity association soils (Taylor, Hailey, and Richmond 1966). These are for the most part grayish brown, alluvial soils occurring throughout the river valley in bottomlands and terraces. The slight elevation upon which the mission structures actually sit is composed of a formation classified by the Soil Conservation Service (ibid:17) as Hilly Gravelly Land (HgD). They describe this as "beds of calcium carbonate consisting of sediments cemented with calcium carbonates" (locally called caliche). On level areas, a mantle of "limy, dark grayish-brown loam or clay loam has formed." This is a very accurate description of the conditions found during this and previous excavations at the site (see Scurlock and Fox 1977:33-37). Apparently the mission site was chosen with care, in order to make maximum use of travertine deposits found near the southwest corner of the compound for building material for this and the other missions, and of the shallowly buried caliche for support of the building foundations. The success of this effort is reflected in the fact that the church at Concepción is the only one which has not collapsed at some point in its history, in contrast to structural problems which have plagued the other mission churches in the San Antonio area.

\section{INVESTIGATIONS}

A block of twelve $1-\mathrm{m}^{2}$ units was laid out so as to examine a section of Smith's recorded walls, where they approached and then crossed the corredor. The intent was to determine the accuracy of Smith's observations and to establish the character and depth of the wall he showed as crossing the corredor. We also needed to establish whether any original floors or occupation surfaces were preserved, such as had been found in the areas of higher elevation at the granary to the east (Ivey and Fox n.d.) and the adobe church to the west (Ivey 1982).

Another block of four $1-\mathrm{m}^{2}$ units was centered over a wall Smith showed as crossing the corredor $1.5 \mathrm{~m}$ south of the first wall. Since this wall section appeared to be in line with one to the west that Ivey suggests was the south wall of the first convento, we wished also to find evidence to prove or disprove this theory. The units were also placed so as to reveal the relationship of this wall to the corredor wall Smith showed as extending south and beyond the fence (Fig. 3).

Finally, a test trench was laid out so as to cross the extension of the north-south convento wall if it existed beyond the point where it stopped in Smith's drawing. The purpose of this test was to determine whether any subsurface structures continued beyond Smith's investigations that would lie in the path of the proposed drain pipe trench.

\section{NORTH WALL UNITS}

Initially, a block of eight $1-\mathrm{m}^{2}$ units (100-107) was laid out over the north wall of the first convento. Later, a 2- $\mathrm{m}^{2}$ unit (109) was added to extend the excavations well beyond the east wall of the corredor in order to determine what Smith had found in that area.

Units 101 and 102 contained slight mounding above the surrounding ground surface due to the presence of the remains of the north-south extension of the second convento wall (Fig:4). The first level in each of these units was therefore designated as Level $1+$ and was excavated to the datum level. Contents of Levels $1+$ and 1 in the north 


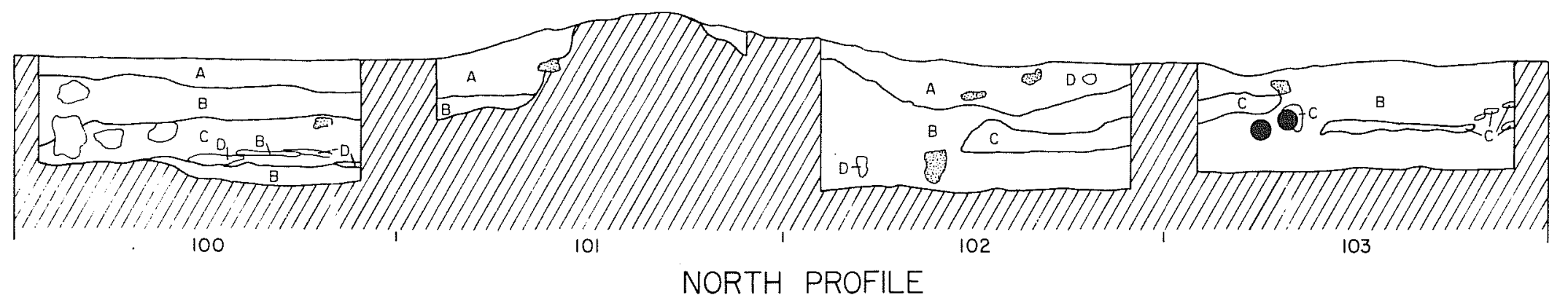

$\begin{array}{lll}\text { A-10YR 5/2 } & \text { Grayish Brown } & \text { Dry Loamy Clay } \\ \text { B-10YR 4/2 } & \text { Dark Grayish Brown } & \text { Loamy Clay } \\ \text { C-10YR 7/4 } & \text { Very Pale Brown } & \text { Disintegrating Stone } \\ \text { D- IOYR 8/2 } & \text { White } & \text { Caliche } \\ \text { E-1OYR 5/1 } & \text { Gray } & \text { Calcareous Clay } \\ \text { F- IOYR 5/3 } & \text { Brown } & \text { Compact Loamy Clay } \\ \text { G-7.5 YR 4/2 } & \text { Dark Brown } & \text { Loamy Clay With Sand }\end{array}$

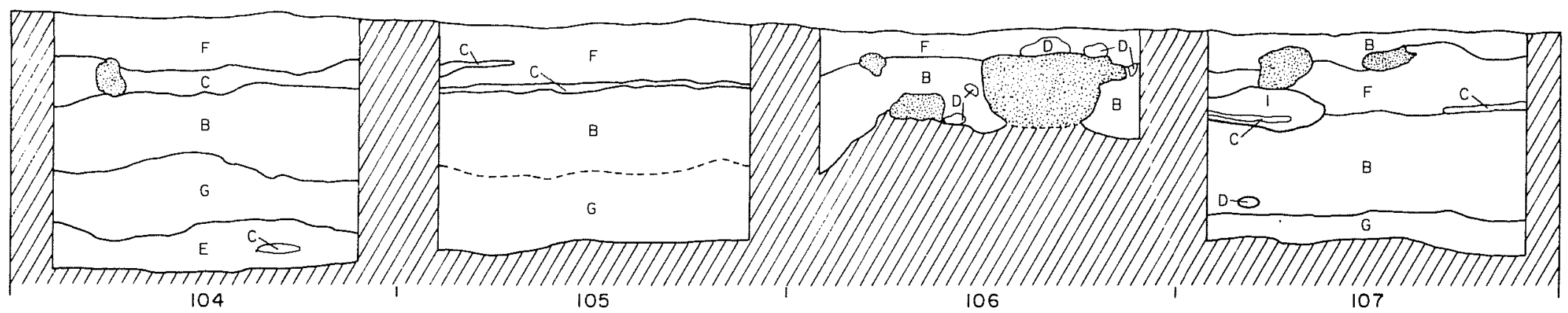

SOUTH PROFILE

Figure 4. Profiles of North Wall Units. 
wall units included grass roots and gravelly, grayish brown to brown clay loam. Artifacts were minimal except in Units 107 and 109, which yielded a surprising variety of materials, ranging from 18th-century tin-glazed earthenware sherds made in Puebla, Mexico, to a U.S. penny dated 1963.

The second level had much the same type of soil, but fewer artifacts. Again, the majority of the materials came from Units 107 and 109, and were totally mixed as to time period. The top of an east-west wall of travertine blocks 1 -m wide was clearly defined across the units when this level was completed. The only major disturbance noted was the installation of two PVC electrical conduits which crossed Units 103 and 109 from northwest to southeast. The trench for these lines penetrated to the bottom of Level 2 and cut a shallow trench across the top of the travertine wall foundation (Fig. 4).

Level 3 also contained gray brown clay loam. Other than fragments of animal bone, few artifacts were found in this level. Units 100 and 101 and part of Unit 102 were not excavated below Level 2, in order to protect the remains of the convento wall foundation from erosion.

Levels 4, 5, and 6 were excavated through compact dark brown sterile clay which graded to gray as it approached caliche bedrock at about $60 \mathrm{~cm}$ below the surface. The bottom of the north-south, second convento wall sat on the dark brown clay at ca. $40 \mathrm{~cm}$ below the surface. The wall appears to have been built over the ruins of the first convento wall. No trace was found of the east wall of the corredor that Smith shows running north-south across the line of the first convento's north wall, despite excavations extending to bedrock in Unit 107 and well below the top of the north wall foundation in Unit 103. No indication of a floor or a recognizable occupation surface was found in the north wall units. The intermittent lenses of pale brown, crumbled travertine encountered throughout the excavations (Fig. 4) bear no observable horizontal or vertical relationship to the presence, absence, or frequency of artifacts.

\section{SOUTH WALL UNIT}

The south wall unit (108) was $2 \mathrm{~m}^{2}$ and was excavated in quadrants. The stratification was found to be the same as that of the north wall units. Excavation was continued only to dark brown sterile clay at $40 \mathrm{~cm}$ below datum, which was just below the level of the bottom of the north-south, second convento wall as it crossed the area. A substantial travertine wall was found east-west across the unit (Fig. 5). It was identical in every way to the section of the first convento north wall previously exposed and was $1 \mathrm{~m}$ in width.

Artifacts recovered during excavation of Unit 108 represented both the 18 th century and the 19 th century. They were most numerous in the second level, particularly in the northeast quadrant. From this point the artifact frequency dropped rapidly, partly because most of the unit was taken up by the two perpendicular wall foundations. A 2-cm metal pipe serving as an electrical conduit crossed this unit northwest to southeast just beneath the surface. It passed over the top of the foundations.

\section{WALL CONTINUATION UNITS}

Unit 110 was a test trench measuring $1 \mathrm{~m}$ by $2-1 / 2 \mathrm{~m}$, placed outside the park fence. It was located so as to cross the line of the north-south wall exposed in Unit 108 and indicated by Smith to continue beyond the fence for a short distance. The east $75 \mathrm{~cm}$ of this unit was dug in $20-\mathrm{cm}$ levels to bedrock. Then the rest of the trench to the west was excavated in one level to $25 \mathrm{~cm}$ to be sure that the wall did not continue in this direction.

The first level of Unit 110 consisted of very dark gray brown clay loam containing substantial amounts of smallsized gravel in the lower part. This level also contained a wide variety of 18 th century, 19 th century, and 20th century artifacts, including nails and other construction materials, ceramic drain pipe fragments, glass and ceramic sherds, plastic fragments, and animal bone. There was no stratification in the deposits. The soil in Level 2 was similar but more compact. The artifacts continued to represent a broad time period, and there was more animal bone. As in the other excavations, little was found below this level but a chert fragment and a few pieces of bone. A deep test to $60 \mathrm{~cm}$ revealed caliche bedrock as in the previous excavations. 


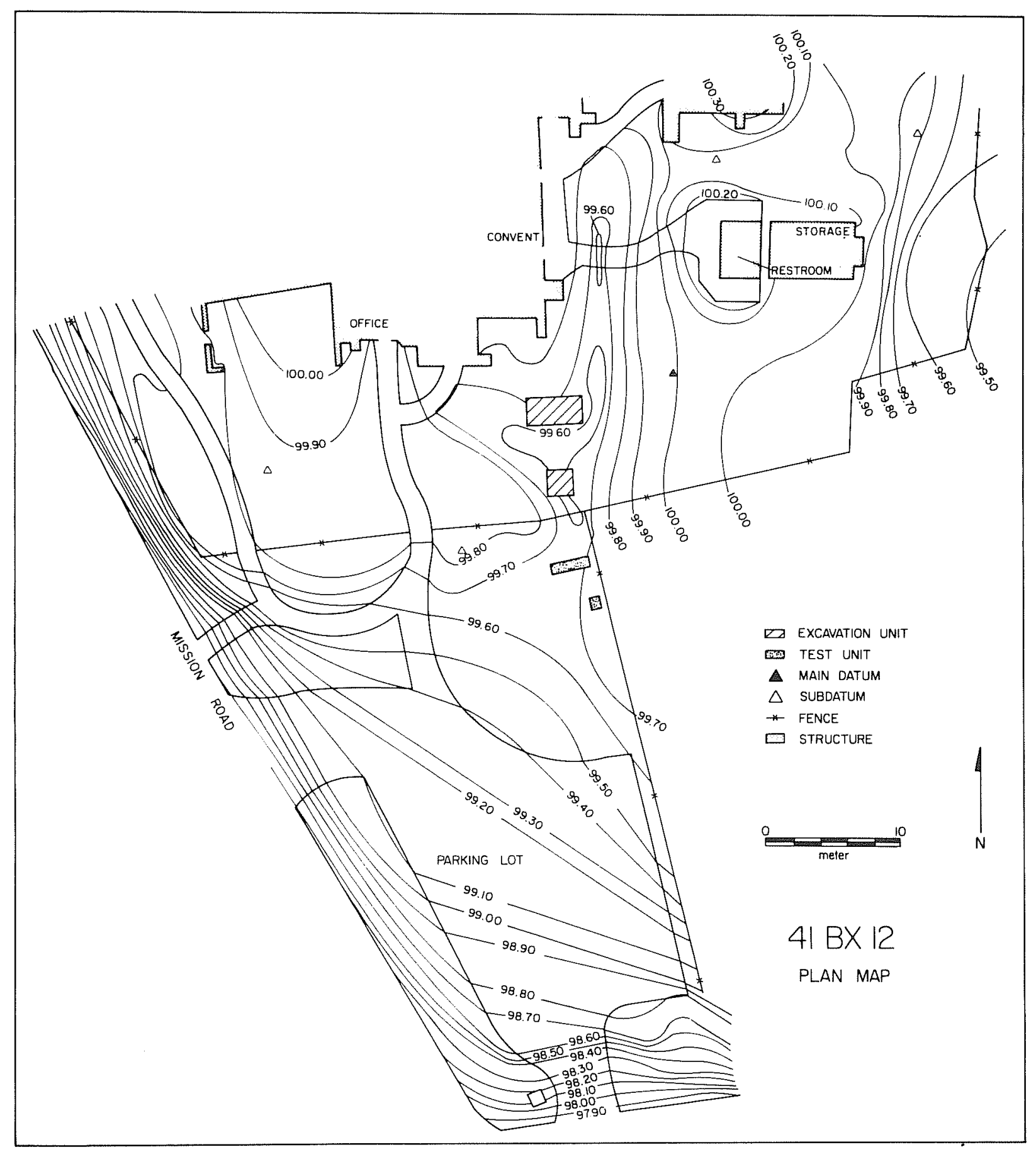

Figure 5. Plan of Project Area. 
In the west end of the unit, the deposits appeared to be comparatively late and disturbed. A large chunk of modern concrete containing a piece of iron reinforcing rod was found at $20 \mathrm{~cm}$ in the center of the area. No sign of a northsouth wall was found, nor were any early floors or other surfaces preserved in this unit.

Two meters south of Unit 110, a 50- $\mathrm{cm}^{2}$ shovel test revealed the same confused situation as in Unit 110.

\section{ARTIFACT ANALYSIS}

For analysis, the artifact collection is divided into categories that reflect their use in the everyday life of the site's inhabitants (Table 1). This is done to better understand what sort of activities the collection represents, i.e., disposal of domestic trash, dismantling of a structure, etc., as well as to facilitate the comparative dating of various strata by visually demonstrating their contents. The ceramics are dealt with in particular detail because of their usefulness in determining the origin of the deposits both by date and by country of origin.

\section{KITCHEN/DINING ITEMS}

\section{CERAMICS}

Ceramic type descriptions are minimized in this report since the collection is comparatively small, and the variation in types is limited. For more detailed descriptions of the specific ceramic types see Davis and Corbin (1967:1430), Schuetz (1969:7-26, 50-58), Fox, Bass, and Hester (1976:54-67), and Ivey and Fox (1981:30-35).

\section{Unglazed Wares}

There are two varieties of unglazed utility wares represented in the collection. One variety, commonly called Goliad ware, is handmade of local clay. It is characteristically red brown to tan with a black core due to the low temperature at which it is fired. Small, white bone inclusions are usually present in varying amounts. At 18th-century Spanish colonial sites in the San Antonio River valley, this ware generally is by far the most prevalent ceramic type found. A total of 25 sherds was recovered in the excavations. Goliad ware apparently continued in use into the early 19 th century in Spanish households in San Antonio.

Another type of unglazed ceramic ware found in much lesser amounts in Spanish deposits is wheel-made Valero ware. It is pinkish tan with a fine homogeneous paste. Four sherds of Valero ware were found during the excavations, all in the first level of the north wall units. Earlier controlled excavations at MissionConcepción (Ivey and Fox n.d.) suggest that Valero ware was popular between 1730 and 1760 at this site.

\section{$\underline{\text { Red Burnished Ware }}$}

Two sherds of red ware, burnished on both surfaces, were found in Level 1 of Unit 107. Apparently a continuation of pre-Columbian traditions, this ware is still made in some areas of Mexico (Ivey and Fox 1981:31). A few sherds are found at most Spanish colonial sites in central Texas.

\section{Lead-Glazed Utility Wares}

Lead-glazed utility wares can be divided into two basic types. One is wheel-made with sandy orange paste and yellow orange to olive green glaze, and the other has fine red paste and was mold-made. For the former we have little dating information other than that it appears to have been in use throughout the 18th century. Eight sherds were found distributed fairly evenly throughout the deposits. The type with fine red paste, called Galera ware 
TABLE 1. PROVENIENCE OF ARTIFACTS

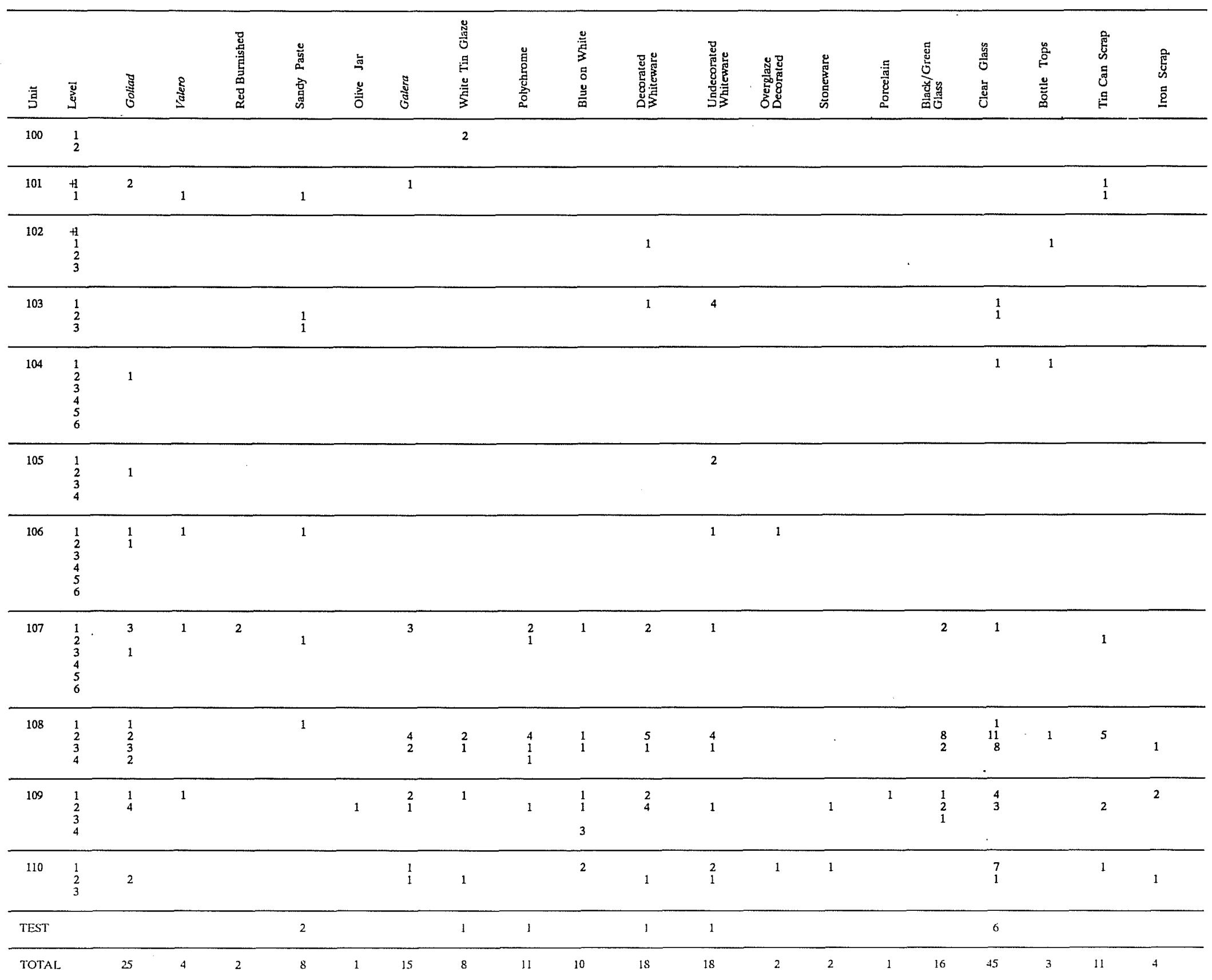


TABLE 1. (continued)

$\varpi$

\begin{tabular}{|c|c|c|c|c|c|c|c|c|c|c|c|c|c|c|c|c|c|c|c|c|c|c|c|c|}
\hline 泀 & $\overrightarrow{\mathrm{g}}$ & 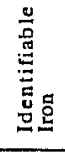 & & $\begin{array}{l}\overline{\mathbf{z}} \\
\mathrm{w} \\
\overline{\mathrm{g}} \\
\frac{\mathrm{g}}{2} \\
\end{array}$ & 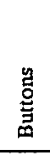 & 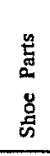 & $\frac{\mathrm{G}}{\mathrm{s}}$ & 尊 & 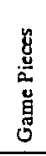 & $\underline{y}$ & 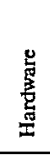 & 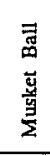 & 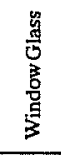 & $\begin{array}{l}\frac{y}{\tilde{f}} \\
z \\
\bar{z} \\
\end{array}$ & 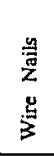 & 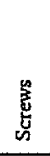 & 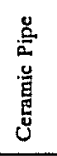 & 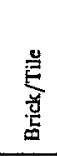 & 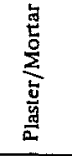 & $\stackrel{\overrightarrow{\mathrm{g}}}{\mathrm{E}}$ & $\frac{\underline{\underline{u}}}{\frac{\vec{y}}{2}}$ & 훌 & 僾 & 唃 \\
\hline 100 & $\frac{1}{2}$ & & 11 & & & & & 1 & & & & & & & & & & 3 & & & 8 & & & $\begin{array}{r}25 \\
0\end{array}$ \\
\hline 101 & $\begin{array}{c}+1 \\
1\end{array}$ & & $\begin{array}{l}4 \\
9\end{array}$ & 1 & & & & & & & & & 1 & 1 & & & & $\frac{1}{1}$ & & & & & & ${ }_{14}^{11}$ \\
\hline 102 & $\begin{array}{c}+1 \\
1 \\
2 \\
3 \\
3\end{array}$ & & $\stackrel{2}{5}$ & 1 & 1 & & 1 & & 1 & 1 & & & 4 & & 1 & & & 1 & & 2 & & 4 & & $\begin{array}{r}3 \\
22 \\
0 \\
1\end{array}$ \\
\hline 103 & $\begin{array}{l}\frac{1}{2} \\
\frac{3}{3}\end{array}$ & & $\begin{array}{l}18 \\
12\end{array}$ & & & & & & & 1 & 1 & & $\begin{array}{l}3 \\
1 \\
1\end{array}$ & 1 & 1 & & & $\begin{array}{r}4 \\
49 \\
6\end{array}$ & & 1 & 2 & & & $\begin{array}{r}35 \\
67 \\
8\end{array}$ \\
\hline 104 & $\begin{array}{l}1 \\
2 \\
3 \\
4 \\
5 \\
6\end{array}$ & & $\begin{array}{r}10 \\
9 \\
10 \\
1\end{array}$ & & & & & & & & & & 1 & & & & & 2 & & $\begin{array}{l}\frac{1}{2} \\
1 \\
1\end{array}$ & 2 & & 3 & $\begin{array}{r}20 \\
11 \\
12 \\
2 \\
0 \\
1\end{array}$ \\
\hline 105 & $\begin{array}{l}\frac{1}{2} \\
\frac{3}{3} \\
4\end{array}$ & & $\begin{array}{r}10 \\
2 \\
1\end{array}$ & & & & & & & & & & 1 & & 1 & & & & & $\begin{array}{l}1 \\
1\end{array}$ & 2 & & & $\begin{array}{c}17 \\
3 \\
1 \\
1\end{array}$ \\
\hline 106 & $\begin{array}{l}1 \\
2 \\
3 \\
4 \\
5 \\
6\end{array}$ & & $\begin{array}{r}7 \\
14\end{array}$ & $\begin{array}{l}1 \\
1\end{array}$ & & & & & & & 1 & & 1 & & & & & & & $\frac{1}{1}$ & & & & $\begin{array}{r}16 \\
17 \\
0 \\
0 \\
0 \\
0\end{array}$ \\
\hline 107 & $\begin{array}{l}1 \\
2 \\
3 \\
4 \\
5 \\
6\end{array}$ & & $\begin{array}{r}47 \\
71 \\
3\end{array}$ & 2 & & & & & & & & & 1 & 1 & 1 & & & $\begin{array}{l}8 \\
1\end{array}$ & 3 & $\begin{array}{l}2 \\
1\end{array}$ & 8 & & & $\begin{array}{r}90 \\
76 \\
1 \\
3 \\
1 \\
0\end{array}$ \\
\hline 108 & $\begin{array}{l}1 \\
2 \\
3 \\
4\end{array}$ & & $\begin{array}{c}8 \\
113 \\
90 \\
33\end{array}$ & 2 & & & & & 1 & $\begin{array}{l}4 \\
2 \\
1\end{array}$ & & & $\begin{array}{r}2 \\
56 \\
26 \\
1\end{array}$ & $\begin{array}{r}11 \\
2 \\
1\end{array}$ & 5 & 2 & & $\begin{array}{r}8 \\
12\end{array}$ & 1 & $\begin{array}{l}5 \\
1\end{array}$ & ${ }_{1}^{4}$ & 1 & & $\begin{array}{r}144 \\
256 \\
157 \\
41\end{array}$ \\
\hline 109 & $\begin{array}{l}1 \\
2 \\
3 \\
4\end{array}$ & 1 & $\begin{array}{r}56 \\
138 \\
14 \\
1\end{array}$ & & 1 & 1 & & 1 & & & & 1 & $\begin{array}{r}10 \\
12 \\
2\end{array}$ & $\begin{array}{l}4 \\
2\end{array}$ & $\begin{array}{l}6 \\
8\end{array}$ & & & $\begin{array}{r}13 \\
21 \\
2\end{array}$ & & ${ }_{2}^{2}$ & 7 & $\begin{array}{l}3 \\
1\end{array}$ & & $\begin{array}{r}118 \\
209 \\
17 \\
6\end{array}$ \\
\hline 110 & $\begin{array}{l}1 \\
2 \\
3\end{array}$ & & $\begin{array}{r}42 \\
113 \\
2\end{array}$ & 1 & & & & & & & 2 & & $\begin{array}{l}4 \\
6\end{array}$ & $\begin{array}{l}2 \\
1\end{array}$ & $\begin{array}{l}8 \\
6\end{array}$ & & 9 & 1 & $\begin{array}{r}20 \\
2\end{array}$ & $\begin{array}{l}1 \\
1 \\
1\end{array}$ & 5 & 1 & 14 & $\begin{array}{c}110 \\
152 \\
3\end{array}$ \\
\hline TEST & & & 15 & & & & & & & 1 & 1 & & 1 & 1 & 5 & & & 14 & 5 & 3 & 15 & & & 73 \\
\hline TOTAL & & 2 & 871 & 9 & 2 & 1 & 1 & 2 & 2 & 10 & $s$ & 1 & 134 & 27 & 42 & 2 & 9 & 1.47 & 31 & 31 & 54 & 10 & 17 & 1614 \\
\hline
\end{tabular}


throughout the southwest, appeared in Texas about 1750 (ibid.:34). Fifteen of these sherds are in the collection, concentrated mainly in the second and third levels of Units 108 and 109.

A ceramic type that occasionally bears a green lead glaze on one face of a pinkish tan sherd is the olive jar. These were used as shipping containers for olive oil and wine on ships around the world, and apparently a few ended up on the frontier (Ivey and Fox 1981:34). Only one such sherd was found during these excavations.

\section{Tin-Enameled Wares}

Tin-enameled ware (Fig. 6,a-d) was made in Mexico and brought to Texas in small quantities throughout the 18th and early 19 th centuries. Sherds of this type found during these excavations primarily date to the post-1800 period.

They have a relatively hard, red paste and are decorated in shades of blue green to green and red brown, with occasional touches of yellow or gold (Lister and Lister 1974:12). Ceramics of this variety were probably from the household of the Yturri family who lived in the nearby granary from 1823 to 1838 . Two polychrome sherds with buff-colored paste representing designs found in the late 18th century are also in the collection. All these sherds have been included in the polychrome classification for this analysis.

Ten blue on white tin-glazed sherds in the collection are really too small to be able to determine their date of manufacture by the patterns they represent. Since blue on white decoration was popular throughout the 18th century and into the early 19th century, they fit the time period of the rest of the collection. Seven plain white tinglazed sherds in the collection cannot be confidently linked to any time period.

\section{White Earthenwares}

In the early 19th century as Anglo American settlers began to arrive in Texas, so also did English-made white or refined earthenwares. In the San Antonio area, these wares were present by the early 1830s (Fox 1986:122). The whitewares in this collection are both decorated (18) and undecorated (18) sherds. Decorated sherds (Fig. 6,e-k) have transfer-printed, hand-painted, spattered, blue shell-edged, and banded slip decorations. The patterns represented date to the first half of the 19 th century, and probably represent the occupation of the Yturri family. The undecorated sherds may be parts of decorated vessels or plain whiteware. Two sherds of whiteware in the collection have traces of overglaze decal designs. They are both from the first level of excavation, and would probably date to the early 20th century, when this type of decoration became popular (Fox et al. 1974:220).

\section{Stoneware}

Two sherds of stoneware utility vessels are in the collection. Jugs, crocks, churns, and jars of this material were in use in the San Antonio area from the late 19th century into the early 20th century. One sherd with a greenish slip on the outside and Albany slip on the inside probably was made at the Meyer kiln near Atascosa, Texas (see Greer and Black 1971). The other sherd bears an unusual thick, gray slip on both surfaces, and is probably not Texasmade.

\section{$\underline{\text { Porcelain }}$}

One portion of the handle from a porcelain tea cup is in the collection. The fragment is too small to observe much else about it. 


\section{GLASS CONTAINERS}

Sixteen fragments of colored glass were recovered during the excavations. These probably represent brown wine or beer bottles, "black glass" and olive green wine bottles, and aqua soda water bottles. Forty-five clear glass fragments represent various types of containers. All pieces are too small to identify the shape or age of the vessels from which they come.

Three crown bottle caps were also found, one in the first level of Unit 104, and one each in the second levels of Units 102 and 108. These came into use after 1892 (Kendrick 1966:49).

\section{METAL SCRAP}

A relatively small amount of metal scrap is in the collection, most of it seemingly fragments of tin cans. Among these is one nearly whole sardine can from Level 2 in Unit 108.

\section{SUBSISTENCE}

\section{Animal Bone}

A comparatively large number of bone fragments (871) were found during excavations. Bone was present to the 40-cm level in most units. Most of the pieces were too fragmentary to be identifiable. A cursory examination suggests that cow, sheep/goat/deer, medium-sized fish, and a small robin-sized bird are represented. All but the last one were probably food resources and readily available to the 18 th- and 19 th-centuries inhabitants of the site. Since there was no clear stratigraphy in the artifact-bearing levels, further analysis of the bone would be nonproductive.

\section{Mussell Shell}

Small fragments of river mussel shell were found occasionally. These were in levels that also contained historic artifacts, and they could have been a food item. None of the pieces are large enough to be diagnostic.

\section{CLOTHING AND PERSONAL ITEMS}

\section{BUTTONS}

A contemporary wooden button (Fig. 6,m) was found in Level 1 of Unit 102. This machine-made object probably came from the coat or jacket of a comparatively recent visitor to the park. A black plastic button (Fig. 6,n) came from Level 2 of Unit 109. This is probably contemporary with the glass and turn-of-the-century ceramics in this level.

\section{SHOE PARTS}

A fragment of a worn composition heel from a relatively modern shoe was found in Level 2 of Unit 109. It probably dates to at least the first quarter of this century. It is marked with a raised "15" on the upper, unworn surface. 
Figure 6. A Selection of the Antifacts Recovered.
a, tin-enameled earthenware, blue on white;
$b$, tin-enameled earthenware, red brown and green on white;
c, tin-enameled earthenware, red brown on white;
d, tin-enameled earthenware, pale blue, pale yellow, brown on white;
e, white earthenware with mocha design;
f, white earthenware with banded slip design;
$\mathrm{g}$, white earthenware with brown transfer design;
$h$, white earthenware with blue transfer design;
i, white earthenware with blue and red hand-painted design;
$\mathrm{j}$, white earthenware with blue, green, and gold hand-painted design;
$\mathrm{k}$, white earthenware with blue-edged design;
1, Valero ware disk;
$\mathrm{m}$, wooden button;
n, black plastic button;
o, clay marble;
p, lead ball. 
ARTIFACT ANALYSIS

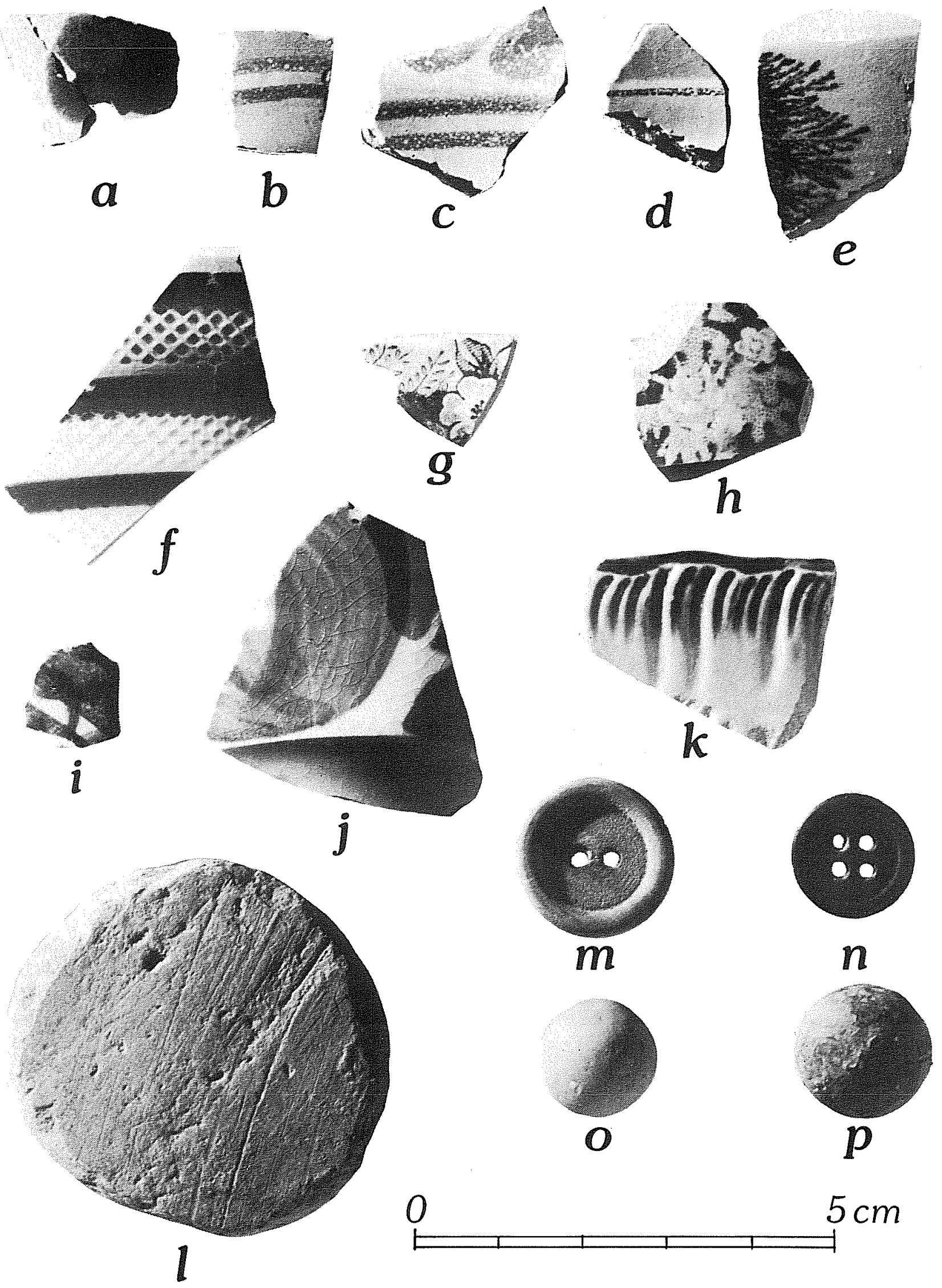




\section{MIRROR}

A broken, rectangular mirror with slightly rounded corners came from the top of Unit 102. It resembles the mirror that once was included in most women's new handbags, and probably was dropped by a 20th-century parishioner or park visitor.

\section{COINS}

Two comparatively recent coins were found, a 1963 U.S. penny and a 1943 U.S. mercury dime. The former was in the first level of Unit 100, the latter in the second level of Unit 109.

\section{GAME PIECES}

Up against the north side of the north wall foundation in Level 3 of Unit 102 a disk was found fashioned from a sherd of heavy, unglazed Valero ware (Fig. 6,1). Similar objects of stone and ceramics have been found at the other missions (Schuetz 1969:Plate 32) and at other sites in southwest Texas (Folan et al. 1986:31). A small, unglazed clay marble (Fig. 6,0) came from Level 1 in Unit 108. These are common in late 19th-century sites throughout the state.

\section{STABLE/WORKSHOP ITEMS}

Ten pieces of wire and five pieces of broken hardware from unidentifiable objects are represented in the collection as stable or workshop items.

\section{$\underline{\text { ARMS }}$}

A .69 caliber lead ball (Fig. 6,p) was found in Level 1 of Unit 109. Such projectiles generally date to the 18th and early 19th centuries in San Antonio sites (see Nesmith 1986:77). The fact that it was in the first level of the excavations suggests there may be considerable disturbance in the deposits.

\section{CONSTRUCTION ITEMS}

\section{WINDOW GLASS}

Numerous fragments of flat glass were found throughout the excavations at various levels. By far the majority of the fragments are $3 \mathrm{~mm}(1 / 8 \mathrm{inch})$ in thickness and are clear glass. Scattered among these are a few $1.5-\mathrm{mm}(1 / 16-$ inch) pieces. The latter are more patinated and tend to have a faintly blue cast. The thicker panes are probably more recent.

\section{CUT NAILS}

Of the nails recovered, 27 are cut nails, square in cross section. These were in use after ca. 1800 (Fontana and Greenleaf 1962:54) and continued to be popular until about 1900 in Texas. 


\section{WIRE NAILS}

Forty-two wire nails were found in the first and second levels of most of the units. These were not available in San Antonio until the last decade or so of the 19th century. The fact that in nearly every case, this type of nail was found in close proximity to cut nails could indicate disturbance in the deposits.

\section{CERAMIC PIPE}

Nine fragments of glazed ceramic drain pipe were recovered from the first level of Unit 110. Their presence in the first level suggests that they had been disturbed from their original location.

\section{BRICK/TILE}

Altogether, 147 pieces of brick and tile were found. Most of these are very small chunks of red brick or tile from 5 to $10 \mathrm{~mm}$ across. Larger fragments indicate that some of these represent modern hollow tile. There are also a few pieces of pink and charcoal gray bricks, primarily from Unit 110, outside the park fence.

Four fragments of Spanish colonial brick were recovered from Level 1 of Unit 109 that appear to be from the same brick or tile. It is $25 \mathrm{~cm}$ (ca. one inch) thick and $10.8 \mathrm{~cm}$ (4-1/2 inches) wide. The length cannot be determined. Fragments of similar tiles, or ladrillos, have been found at all the San Antonio missions.

\section{PLASTER/MORTAR}

The plaster and mortar recovered were made with cement and would date post-1880. No Spanish colonial period mortar or plaster was observed during excavation. This is unusual for such a site, and may indicate the removal of everything above the level of the foundations at an early date.

\section{SCREWS}

Two wood screws were found in Level 3 of Unit 108. It is interesting that these comparatively modern artifacts were found at a level below numerous Spanish colonial artifacts.

\section{CHERT}

Thirty-one chips and flakes of chert came from all levels of the excavation. No diagnostic artifacts were among them, and many were probably accidental inclusions in the soil. A patinated flake recovered from Level 6 in Unit 104 is definitely manmade and may have arrived at that depth during construction of the north wall footings.

\section{MISCELLANEOUS ITEMS}

Fragments of plastic and unidentifiable paper were found. Most of the plastic from Unit 110 is black polyethylene sheeting. Crumbled balls of aluminum foil were also recovered in several units.

These materials are all considered to be fairly recent, and their presence could indicate disturbance of the deposits by man or by rodents. Several rodent burrows were found during excavations, particularly around the north wall footings. 


\section{CONCLUSIONS}

The primary purpose of the test excavations was to determine a possible route for the proposed drain pipe trench. On the basis of our findings, it appears that it would be possible to install a shallowly buried pipe in the line of the corredor along the eastern side of the second convento, extending south from the convento along and parallel to the fence on the east side of the parking lot, discharging at the edge of the street south of the lot. There are no preserved floors or living surfaces that would be crossed by this trench. The levels that would have included them appear to have been disturbed and probably have been totally removed.

The tops of the two existing foundation walls that remain across the proposed route lie ca. $20 \mathrm{~cm}$ below the present surface, and the top of the north wall foundation has already been disturbed by the installation of two electrical conduits. Balancing the eventual damage that will result to the convento and its frescoes by intermittent flooding of the rooms, against minor disturbance to a small section of the buried foundations, it would seem prudent to install the drain. We do, however, recommend that the portion of the pipe trench that passes through the area inside the park fence be carefully excavated by hand rather than by machine. This should be done under the supervision of the park's archaeologist.

As usual with archaeological field work, a number of other questions have arisen in the process of this investigation. Most of these questions are continuing ones for which these brief tests provide a few more facts to add to the information obtained in previous years by Scurlock and Ivey (see Fig. 5).

We now have further evidence to confirm our previous suspicions that Smith's map of foundations in this area was made partly on the basis of shallow cleaning of the surface and partly on extending the lines of walls already in existence. If he had excavated as little as $10 \mathrm{~cm}$ deeper, he would have found the exact outlines of the first convento walls. He would also have determined, as our excavations showed, that the east wall of the corredor does not extend south across the line of the first convento as he has shown it.

The mystery still unsolved is what happened to the Spanish colonial floors and occupational debris in this area. The fact that these things still exist intact at higher elevations to the east and west suggests that some major earth removal has taken place in the low area at some point in time, probably before or during the 19th-century occupation of the mission buildings. Perhaps this was an early attempt to solve the drainage problem that still plagues the mission today.

\section{REFERENCES CITED}

Bexar County, Texas

Bexar County Archives (BCA)

Originals and microfilm located in the basement of the Bexar County Courthouse, San Antonio, Texas.

Bexar County Deed Records (BCDR)

Originals and microfilm located in the basement of the Bexar County Courthouse, San Antonio, Texas.

Castañeda, C. E.

1936 The Mission Era: The Founding of Texas, 1519-1693. Our Catholic Heritage in Texas, 1519-1936. Vol. I. Von Boeckmann-Jones Company, Austin. 
Cisneros, J. A.

1980 San Antonio Missions National Historical Park, San Antonio, Texas. Statement for Management. U.S. Department of the Interior and National Park Service.

Corner, W.

1890 San Antonio de Bexar: A Guide and History. Bainbridge and Corner, San Antonio, Texas.

Davis, E. M. and J. E. Corbin

1967 Archeological Investigations at Washington-on-the-Brazos State Park in 1966. State Building Commission Archeological Program, Report 5.

Dolores y Biana, Fr. M. F. de los

1759 Testimonio de la Visita de las Misiones. Old Spanish Missions Historical Research Library, Our Lady of the Lake University, San Antonio, Texas.

Folan, W. J., I. W. Cox, A. A. Fox, and G. M. Hinojosa

1986 Laredo, Texas: Gateway Community on the Texas Borderland. Archaeological and Historical Investigations for the Laredo City Toll Plaza. Center for Archaeological Research, The University of Texas at San Antonio, Archaeological Survey Report 116.

Fontana, B. L. and J. C. Greenleaf

1962 Johnny Ward's Ranch: A Study in Historic Archaeology. The Kiva 28(1-2).

Fox, A. A.

1986 Ceramics. In La Villita Earthworks (41 BX 677): San Antonio, Texas, assembled by J. H. Labadie:107-127. Center for Archaeological Research, The University of Texas at San Antonio, Archaeological Survey Report 159.

Fox, A. A., F. A. Bass, Jr., and T. R. Hester

1976 The Archaeology and History of Alamo Plaza. Center for Archaeological Research, The University of Texas at San Antonio, Archaeological Survey Report 16.

Fox, D. E., R. J. Mallouf, N. O'Malley, and W. M. Sorrow

1974 Archeological Resources of the Proposed Cuero I Reservoir, DeWitt and Gonzales Counties, Texas. Texas Historical Commission and Texas Water Development Board, Archeological Survey Report 12.

Furey, F. J., Archbishop

1974 Archdiocese of San Antonio, 1874-1974. Archdiocese of San Antonio, Texas.

Greer, G. H. and H. Black

1971 The Meyer Family: Master Potters of Texas. Trinity University Press, San Antonio. 
Habig, Fr. M. A.

1968 The Alamo Chain of Missions, A History of San Antonio's Five Old Missions. Franciscan Herald Press, Chicago.

Hatcher, M. A., translator

1919 Texas in 1820, by Juan Antonio Padilla. Southwestem Historical Quarterly 23:47-68.

Ivey, J. E.

1982 Draft report on the Archaeological Investigations at the San Antonio Missions, 1982: Manuscript on file, Center for Archaeological Research, The University of Texas at San Antonio.

Ivey, J. E. and A. A. Fox

1981 Archaeological Survey and Testing at Rancho de las Cabras, Wilson County, Texas. Center for Archaeological Research, The University of Texas at San Antonio, Archaeological Survey Report 104.

n.d. Archaeological Investigations at Mission Concepción and Mission Parkway. Center for Archaeological Research, The University of Texas at San Antonio, Archaeological Survey Report 114. In preparation.

Ivey, J. E. and M. B. Thurber

1984 The Missions of San Antonio, A Historic Structures Report and Administrative History. Part I: The Spanish Colonial Missions, edited by Tom Ireland. National Park Service, Southwest Cultural Resources Center, Santa Fe, New Mexico. Draft report on file at the Center for Archaeological Research, The University of Texas at San Antonio.

Kendrick, G.

1966 The Antique Bottle Collector. Edwards Brothers, Ann Arbor, Michigan.

Lister, F. C. and R. H. Lister

1974 Maiolica in Colonial Spanish America. Historical Archaeology 8:17-52.

Munsell Soil Color Charts

1975 Division of Kollmorgen Corporation, Baltimore, Maryland.

Nesmith, S. P.

1986 Analysis of Military Related Artifacts. In La Villita Earthworks (41 BX 677): San Antonio, Texas, assembled by J. H. Labadie:62-106. Center for Archaeological Research, The University of Texas at San Antonio, Archaeological Survey Report 159.

Schuetz, M. K.

1969 The History and Archeology of Mission San Juan Capistrano, San Antonio, Texas. Vol. II. State Building Commission Archeological Program, Report 11. 
Scurlock, D. and D. E. Fox

1977 An Archeological Investigation of Mission Concepcion, San Antonio, Texas. Office of the State Archeologist, Report 28.

Taylor, F. B., R. B. Hailey, and D. L. Richmond

1966 Soil Survey, Bexar County, Texas. U.S. Department of Agriculture, Soil Conservation Service in cooperation with Texas Agricultural Experiment Station, Series 1962 (12). 


